lst International Conference - Global Ethics - Key of Sustainability (GEKoS) | May 15th, 2020 | Bucharest, Romania

\title{
Natural Tourism vs. Cultural Tourism
}

\author{
Ana-Maria DUMITRACHE (SERBANESCU), Oana OPRISAN \\ https://doi.org/10.18662/lumproc/gekos2020/17
}

How to cite: Dumitrache (Serbanescu), A.-M., \& Oprisan, O. (2020). Natural Tourism vs. Cultural Tourism. In A. Grigorescu \& V. Radu (vol. ed.), Lumen Proceedings: Vol. 11. 1st International Conference Global Ethics - Key of Sustainability (GEKoS) (pp. 162-172). Iasi, Romania: LUMEN Publishing House. https://doi.org/10.18662/lumproc/gekos2020/17 


\title{
Natural Tourism vs. Cultural Tourism
}

\author{
Ana-Maria DUMITRACHE (SERBANESCU) ${ }^{1}$, Oana OPRISAN2*
}

\author{
Abstract
}

Considered a social-economic phenomenon that generates benefits, tourism has been defined as: the art of traveling for one's own pleasure. Romania's tourism's main focus is on natural sceneries and its opulent history. Traversed by the Danube, Romania possess a sensitive scenario, which consists of the marvellous and forested Carpathian Mountains, the Coast of the Black Sea and the Danube Delta, which is internationally known to be the largest European delta that is still very well-preserved. The villages, in which people live and preserve traditions of hundreds of years, have the sole purpose of highlighting the natural sets. From the etymological point of view, after most dictionaries, it comes from the English term "to tour", which means travel, carol, regarding the significance of the trip. Regarding tourism, according to the new specifications, it refers to the activities carried out by people, during trips and stays, in places outside the usual residence, for a consecutive period not exceeding one year (12 months), for leisure purposes, for business or other reasons. The main instrument for an economic growth is the cultural tourism, which leads to an economic increase by attracting tourists from out of the host community and who are partially or commonly motivated by their curiosity in history, the artistic, scientific or related components of the local's lifestyle, their realities, traditions and information in regard to a commune, province, cluster or institution. Such a journey's focus is on deepening one's knowledge on the cultural environment, which include the landscapes, the visual and theatrical arts, the way of life, values, traditions and events. The tourism is always looking for new modes of creating "marketable tourism products" as well as a better working and living environment. The cultural-cognitive tourism consists of an interaction among the cultural, ethnic and historical parts of the society or place which are used as a resource for attracting tourists and developing the tourism.

Keywords: Natural tourism; cultural tourism; economic development.

\footnotetext{
1 Bucharest University of Economic Studies, Bucharest, Romania, a.mariadumitrache@yahoo.com

${ }^{2}$ University Ovidius from Constanta, Faculty of Economic Sciences, Constanta, Romania, oana.oprisan@yahoo.com

* Corresponding Author

(C) The Authors, LUMEN Conference Center \& LUMEN Proceedings.

Selection and peer-review under responsibility of the Organizing Committee of the conference
} 


\section{Introduction}

Tourism is a distinct branch of the national economy. From the etymological point of view, according to most dictionaries, it comes from the English term "to tour", which means to travel, to carol, referring to the meaning of trip. With regard to tourism, according to the new specifications, it refers to the activities carried out by people, during travel and stays, in places located outside the usual residence, for a consecutive period not exceeding one year (12 months), for leisure purposes, for business or other reasons [1].

Tourism can uphold the long-term development of the protected areas where we can see an increase in the number of people who come to seek, understand and enjoy more the genuine sceneries. The tourism is being able to and must assist in the protection of the natural resources and of the local population, and those in charge of taking decisions have understood, over time, what is the actual value of this heritage and they want to conserve it [2].

Corresponding to the meaning presented, the main forms of tourism can be identified, namely:

Recreational and leisure tourism - is available to all tourists from different social backgrounds. In particular, the urban population is attracted by nature, while the rural population participates less. It is a type of tourism practiced by all age groups, but especially by the mature population and young people. The duration is variable, predominating the short-term (weekend) or mediumterm tourism, it is carried out at different distances depending on the material possibilities of the tourists. The main purpose of recreational tourism is to change the landscape, which can also be considered when escaping from one nature to another.

Health care tourism (spa or healing) - has its origins in ancient times, when people knew and exploited the healing properties of mineral and thermal waters, heliomarine, mud. It is considered the oldest type of tourism, in which older people participate more. Through the appropriate arrangements, it has the advantage that it is practiced all year round and can be organized according to the accommodation capacities. It is carried out over medium and long distances, in close connection with the duration of the rest leave and the effectiveness of the curative treatment. It needs a specialized infrastructure and special facilities (procedure rooms, medical gymnastics, saunas, baths, mud, etc.) as well as qualified staff, which raises the cost of services [3].

Cultural tourism - includes people who visit tourist attractions belonging to the cultural heritage. It addresses certain categories of 
population (pupils, students, intellectuals); attracts urban and rural population; the duration is limited to a short or medium time. This type of tourism is frequently practiced by tourists in transit, who do not use too much tourist infrastructure. Flows of tourists interested in cultural tourism are heading to the big cities of the world recognized by the old architecture of buildings, museums or concentrations of various tourist attractions (Venice, Florence, Athens, Rome, Paris, London, Beijing, Tokyo, New York).

Educational tourism - includes tourist activities organized for educational purposes, generally for the young age group.

Social tourism - reflects the social stratification (different incomes of the population), for the population with low incomes (or with disabilities) certain social organisms (unions, help houses) offer facilities to be able to be included in the tourist activity. The development of this type of tourism was possible due to the democratization of tourism (the emergence of organized mass tourism) [6].

Complex type tourism - results from the association on the same territory of the other types. It is the most realistic encountered in practice, comprising a large number of tourists of all ages and professions, being practiced especially during holidays and vacations. This type needs a very wide offer, a diversified infrastructure and services. A major element of attractiveness is the gastronomic specificity of a region. The exhibitions and festivals generated by the celebration of wine, beer and other drinks, as well as some culinary assortments are known. Wine production is an independent tourist attraction for certain countries (France, Spain, Italy). The local peculiarities of the famous wine assortments offered to the tourists in the tasting and sale cellars, create continuous tourist flows.

Shopping tourism - is practiced mainly in famous tourist regions, in large cities with galleries and shopping malls, in small shops famous for certain products [4].

\section{Problem Statement}

The World Tourism Organization (WTO) has defined tourists as persons who travel or live in places out of their area of stable residence for a minimum of twenty-four (24) hours but not for more than one consecutive year, for leisure, business or other unrelated to the pursuit of a remunerated activity in the locality concerned. Tourism has become a trendy global recreational activity [5]. 
Tourism is categorized as the strongest economic branch in the world. In 2004, according to the World Tourism Organization, about 623 billion U.S. dollars were obtained in this sector. \$. In 2008, were recorded more than 922 million arrivals from other countries, an increase of $1.9 \%$ if we compare it to 2007.In 2008, there was an increase in international tourism revenues up to US \$944 billion (642 billion euros), which corresponds to an increase in real terms of $1.8 \%$. The tourism sector employsapproximately 100 million people worldwide, which makes it the most importantemployer [10].

Travelling between borders,accounts for 25 and up to 30 percent of the world trade in services.

The recession which has been affecting the world's economy since 2000, has had an impact on the tourism sector, as the international demand had slowed sharply since June 2008 and recorded a drop of approximately $2 \%$ in the global arrivals during the boreal summer months. This descending trend has intensified in 2009 in some of the countries, mainly because of the $\mathrm{H} 1 \mathrm{~N} 1$ virus, and saw a 4\% global decline in that year, with only 880 million arrivals internationally, and a drop-in tourism revenue estimated to $6 \%$ [10].

Because of the consistent financial contribution obtained from the goods and services business and employment opportunities in service industry associated with tourism, this sector is of crucial importance for many countries, such as Egypt, Greece, Lebanon, Spain and Thailand, and for some island nations (Bahamas, Fiji, Maldives).

The service industry includes transportation services (air transportation, cruises, taxis) and hospitality services (accommodation, which includes hotels and resorts, entertainment locations, such as parks, casinos, malls, music revenues, and theaters) [7].

One economistforwarded the suggestion that the word "tour", from an etymological aspect, comes from Latin (casting) and Greek (tornos), with the main meaning of circle - defined as the movement around a central point or an axis. If we take the word "tour" in English, it has acquired the definition of the action of moving in a circle. Therefore, a tour is a round trip and the person who undertakes such a trip is called a tourist [8].

According to other people's opinions, tourism is considered to be "the art of traveling for pleasure". The same author considers tourism as "a leisure activity that consists in traveling or living far from the place where one person has its residence, for pleasure, recreation, enrichment of experience and culture due to the knowledge of new human aspects and unknown landscapes" [9]. 


\section{Research Questions/Aims of the research}

Through this research we want to analyze the possibilities through which Romania can become a qualitative tourist destination, which is focused on its natural and cultural heritage,so that it can meet the standards of the European Union on the provision of products and services until 2021. We also want to highlight the characteristics tourism in the Danube Delta, as an example, as well as the creation of a nuanced image both internally and externally regarding the advantages of the Danube Delta as a tourist destination and the image of its tourist brand.

\section{Research Methods}

In compiling this article, the author used three research methods, as follows:

- the method of fundamental research, which allowed: gathering the necessary information to reflect the current situation in the researched field, concretizing the perspectives for the future, investigations in the form of theoretical studies, which led to the formation of scientifically argued practical conclusions;

- the method of applied research, which had as task the provision of data for the direction of the practical activity, in order to increase the methodical work and the transposition in operational form of some ideas.

- the historiographical method, which was useful for highlighting the most important scientific research, collections of materials and scientific articles on the topic, being applied, in particular, for knowing, explaining and understanding the research topic.

The authors will perform a general SWOT analysis of the Danube Delta territory, which will ensure the integration of the main results of the socio-economic analysis, in strengths, weaknesses, opportunities and threats. With the help of this analysis we want to highlight, in the research, the growth of the Danube Delta as a tourism destination which is integratedand has a rich portfolio of sustainable products and services based on natural and cultural sights,together with relevant marketing activities.

\section{Findings}

The area surrounding the Danube Delta has a significant potential for development towards a more sustainable tourism which is based on the 
natural and cultural riches. Because the tourism in the area is not developed to its full potential, it offers many opportunities for growth.In the above mentioned area, the natural landscape, which is the main capital for tourism, is very sensitive and the growth of the tourism needs to be done very carefully, on a solid planning and with the understanding of the gains and losses which are in accordance to the tourism activities. What canbe a very significant opportunity, is the fact that the type of tourism that is native to that area, also is correspondent to the kind of touring that is currently developing and will continue to do so in the future. The tourism which has at the base the nature, is also linked to extended periods of stay from the tourists, a higher percentage of their average spending and a greatersense of responsibility towards the local communities and biodiversity. The results which have been obtained from the analysis are representative for the vision that has been defined for the area surrounding the Danube Delta, and which is the foundation for three development objectives for the tourism sector.

Takingmeasures requires time and a set of interventions very well organized in stages. The down part of the tourism is the fact that it is dependent on multiple other socio-economic sectors and implies a highly complex network of stakeholders. In the wake of this findings, the planned efforts towards growth and financing in order to advertise the tourism in the Danube Delta area, will have to progressively build regional human and physical capacity, and networks of different economic links between various stakeholders. The accomplishment of the interventions which have been highlighted in the tourism sections of the present document is highly dependent on the moment of the interventions and their success in the other sectors, like transport (in order to improve the access and convenience), education (for the development of the workforce and training skills), health (services high quality social and safety), agriculture and fisheries (better economic links).

These complex issues justify the importance of an already suggested destination management mechanism (local MMD). One of the main aspects of the MMD is to correlate the links with other public, private and nongovernmental bodies, which are operating in important socio-economic fields. The governmental design and practical purpose of the MMD in the Danube Delta should take in the account the relevance of the coordination function.

The culture and the very singular characteristic of the area is the strongest advantage given to the Danube Delta region towards development and classifying it as a highly competitive tourist destination. Nature is certainly the capital that will be at the base of the Danube Delta's attractiveness and its portfolio of attractions. It is highly advised that the main intervention for 
the expansion of the Danube Delta's portfolio and product be focused on the development of the offers on local art and craft (among other things music, arts, souvenirs, etc.), on traditional economic activities (reeds, reed roofs, etc.), provincial cuisine (not only the dishes in the restaurant, but also through cooking presentations, cooking lessons, etc.), traditions and holidays, etc. The infrastructure for visiting, interpreting and developing the product should addto improving the attractiveness of the area in the form of experience in cultural and religious places(museums, churches, monasteries, important historical sites and places, etc.).

Connecting the growth of the tourism in the Danube Delta with the local economy is another very important aspect for this strategic approach. The only possibility for this goal to be achieved is through joint actions in order to create a more favourable climate and to support the instruments necessary for micro, small and medium-sized companies and, in particular, social enterprises, in order to construct an environmentally friendly local economy. An analysis on the tourism businesses from the Danube Delta area has identified many opportunities for those who have entrepreneurial push and want to develop existing local businesses.

\section{GENERAL SWOT ANALYSIS OF THE DANUBE DELTA TERRITOR}

\section{Strengths}

1) Remarkable natural capital (flora and fauna):

- Danube Delta Biosphere Reserve (cormorants and pelicans reservations)

- Razim Sinoe's friendly complex

- NATURA 2000 sites

- return to the Danube.

- interference with the Sf Gheorghe arm (access to the wet area of the delta)

2) Special cultural capital:

- material: fortresses, archeological sites, churches and monasteries

- immaterial: traditions and customs, specific gastronomy

3) Multi-interculturality (secular coexistence of over 10 ethnic groups: Lipovan Russians, Ukrainians, Tatars, Turks, Roma, Greeks, etc.)

4) Favorable climatic conditions for the summer tourist season

5) Potential for capitalizing on green energy sources (renewable)Diversified fish stock

6) International airport located near the territory of the Danube Delta LAG 
7) Recent modernization of the access road to the Murighiol-Razim Lake area

8) Investments in tourist accommodation structures on an upward trend

9) The existence of a considerable number of lakes suitable for leisure activities: boating, sport fishing, canoeing, etc.

10) Completion of certain works for clearing canals, lakes, which offers the possibility to practice leisure walks

\section{Weaknesses}

1) Human capital with migration tendencies due to lack of jobs

2) Low population density

3) Increased unemployment rate

4) Slow adaptation of the rural population to the necessary changes regarding EU integration

5) Negative general demographic balanceLow rate of activity and employmentDeepening the aging process of the rural population, the danger of depopulation of some rural settlements

6) Reducing the number of inhabitants and changing the structure by age groups

7) High level of poverty of the rural population

8) Middle class, poorly represented

9) Insufficient financial resources in providing real support against marginalization and social exclusion

10) Unskilled labor force in rural areas, mainly employed in agricultureLow interest in practicing traditional trades

11) The gap between the training provided by the school and the requirements of the labor market

12) Educational disparities

13) The continuing lack of training, especially for private sector staff

14) Low level of services for education and training

15) Poor participation of the population at all levels of education

16) The reduced practical component of education

17) Poor education infrastructure and facilities

18) Lack of trainers and training programs in activities specific to the rural environment

19) Aged population

20) Unevenly developed social infrastructure

21) Insufficient local budget for carrying out investment projects

22) Lack of tradition of intra and inter-community cooperation

23) Poor exploitation of the local resource, for the creation of added value, by obtaining finished local products 
24) Low capitalization of traditional crafts

25) Reduced capitalization of cultural and historical capital

26) Unmodernized communal roads

27) Total lack of recreation and agreement spaces for locals and tourists

28) Poorly diversified tourist services

29) Poorly developed waste recycling infrastructure

30) Integrated waste collection system not yet implemented

31) Insufficient information of local decision makers corroborated with the lack of expertise in the fields of innovative technologies in agriculture

32) Insufficient awareness of sustainable management of natural resources Lack of a common vision for the economic development of the area

33) Legislative framework without rules to stimulate and attract investments in the area

34) Fragmentation of land ownership

35) Insufficient promotion of customs and traditions in the area

\section{Opportunities}

1) External financing sources for various investment projects

2) Alternative sources of income by capitalizing on agrotourism potential

3) Growing interest in the use of alternative renewable energy sources

4) Increasing interest in the development of microfarms

5) Growing interest in starting new local small businesses

6) Increased investor interest in some areas of the territory

7) Opportunity to develop cross-border trade contacts with Ukraine and Moldova

8) Availability of local authorities for establishing associations / partnerships, in order to access European funds

9) Introduction of fiscal facilities, in order to encourage the practice of tourism by the local population

\section{Threats}

1) Reluctance to change / new approaches / new solutions, local decision makers and local population

2) Free competition of Romanian products, still at a lower level) with those of other European countries, once they enter the Common Agricultural Market

3) Inconsistency of legislative projects in rural areas

4) Demographic decline of the area

5) Migration of skilled labor to other regions in the country / abroad, due to low wages offered in the area

6) Natural risks: drought, floods 
Following the SWOT analysis, we can say that tourism is not just a simple way to carry out commercial activities; it is also an ideological schematization of history, nature and traditions, a schematization that could reshape culture and nature to their true dimensions [2].

\section{Conclusions}

From the point of view of natural assets and anthropic tourist resources, Romania is very well defined, the fundamental tourist attractions are the elements of ethnography, folklore, folk art, nature reserves, spas and the Romanian hunting fund.

In regard of the accommodation units, Romania has a pretty optimistic image for the future, but it still has room for improvement, so it has in mind the developing of new structures and renovating the current ones.

The tourist structures of food and treatment are well represented in comparison with those of leisure and services, that are not well enough endowed from the point of view of the technical - material base. The latter require massive modernizations, but also the introduction of new forms of leisure and the expansion of the service network.

The tourism sector is very firmly connected to civilization and culture, establishing and interdependent relationship between them. Through capitalizing on the natural, human and financial assets made available to it, tourism cause effects in the economic and social sectorsthat lead to increased economic efficiency, progress and civilization.

A wide range of segments in the tourism sector are influenced by a series of demographic, psychological and organizational factors, which determine the manifestation of the touristic demand and its dynamics in Romania.

\section{References}

[1] Cristureanu C. Economy and politics of international tourism. Bucharest: Abeona Publishing house; 1992

[2] Dean MC. The tourist: a new theory of the leisure class; 1976.

[3] Istrate I, Glăvan V. Cultural tourism in Romania - binding of Romanian spirituality everywhere, Economic Tribune no. 5; 1994

[4] Mărculet I. Romania's superlatives. Small encyclopedia. Bucharest: Meronia Publishing House; 2010. 
[5] Mieczkowski Z. World trends in tourism and recreation, New York; 1990.

[6] Patac F. History of trade and tourism. Timisoara: Eurostampa Publishing House; 2008.

[7] Pompei C. Geography of tourism. Cluj Napoca: Focul Viu Publishing House; 2004.

[8] Stăncioiu AF. Dictionary of tourist terminology. Bucharest: Economica Publishing House; 1999.

[9] Stănculescu G. Tourism Technology. Bucharest: Oscar Print Publishing House; 2003.

[10] http://www.quaestus.ro/wp-content/uploads/2012/03/m.-boita-d.ardelean-c.-haiduc.pdf 